\title{
EVALUATION OF REMOTE RESULTS OF SURGICAL TREATMENT OF NODULAR ENDEMIC GOITER WITH AUTOIMMUNE THYROIDITIS
}

\author{
Michael I. SHEREMET ${ }^{1 \bowtie}$, Viktor 0. SHIDLOVSKYI ${ }^{2}$, Olexandr V. SHIDLOVSKYI ${ }^{2}$, \\ Vitaliy V. MAKSYMYUK ${ }^{1}$, Volodimir V. TARABANCHUK ${ }^{1}$, Nina P. TKACHUK ${ }^{1}$, \\ Oleksandr V. BILOOKYI' ${ }^{1}$, Hana Ya. STUPNYTSKA ${ }^{3}$, Galina V. GRYGORUK ${ }^{4}$, \\ Igor 0. MALISHEVSKY ${ }^{5}$, Lalita M. HERASYM ${ }^{6}$, Ala A. HALAHDYNA, \\ Ivanna I. ABRAMCHUK ${ }^{7}$, Natalia V. VATAMANYUK ${ }^{7}$ \\ ${ }^{1}$ Surgery Department No1, Bukovinian State Medical University, Ukraine \\ ${ }^{2}$ Surgery Department, I.Y. Horbachevsky State Medical University, Ukraine \\ ${ }^{3}$ Department of internal medicine and infectious diseases, Bukovinian State Medical University, Ukraine \\ ${ }^{4}$ Department of General Practice (Family Medicine), Physical Rehabilitation and Sports Medicine, \\ Ivano-Frankivsk National Medical University, Ukraine \\ ${ }^{5}$ Department of Oncology and Radiology, Bukovinian State Medical University, Ukraine \\ ${ }^{6}$ Department of Surgical Dentistry and Maxillofacial Surgery, Bukovinian State Medical University,Ukraine \\ ${ }^{7}$ Department of Therapeutic Stomatology, Bukovinian State Medical University
}

Received 07 Sept 2018, Accepted 26 Nov 2018

https://doi.org/10.31688/ABMU.2018.53.4.08

\begin{abstract}
Introduction. Autoimmune thyroiditis is one of the most important problems of modern endocrinology, with inadequately studied etiological and pathogenic mechanisms of development. It is characterized by the lack of objective and reliable diagnostic methods, effective treatment methods, uncertain therapy or indications for the choice of treatment methods.

The aim of the study. Determination of markers for prediction of clinical course and choice of surgery' volume in patients with nodular goiter and autoimmune thyroiditis, taking into account the oxidative, autoimmune and apoptotic processes.
\end{abstract}

Material and methods. A total of 95 patients who were operated for a nodular endemic goiter on the

\section{Résumé}

L'évaluation des résultats à distance du traitement chirurgical du goître nodulaire endémique associé à la thyroïdite auto-immune

Introduction. La thyroïdite auto-immune est l'un des problèmes les plus importants et les plus actuels de l'endocrinologie moderne, avec des mécanismes de développement étiologiques et pathogéniques insuffisamment étudiés. Elle se caractérise par le manque de méthodes de diagnostic objectives et fiables, de méthodes de traitement efficaces, de tactiques thérapeutiques incertaines et d'indications du choix des méthodes de traitement.

Le but de l'étude. Détermination des marqueurs permettant de prédire l'évolution clinique et le choix 
background of autoimmune thyroiditis were examined. The status of pro- and antioxidant systems, the activity of proinflammatory cytokines, hormonal function of thyroid gland, the level of antibodies to thyroperoxidase, thyroglobulin antibodies and ultrasound structural changes in the thyroid gland have been evaluated in all patients, before and after surgery.

Results. In patients with nodular endemic goiter and autoimmune thyroiditis, in the remote period after surgical treatment, there is a significant increase in the peroxide oxidation index and a decrease in the activity of antioxidant defense systems, against the suppression of apoptotic processes and the activation of pro-inflammatory cytokines. These processes lead to functional failure, hyperplasia and the progression of structural thyroid abnormalities, with progression of the functional incapacity of the thyroid gland and inadequate long-term outcome of treatment.

Conclusions. The study allowed to clarify the indications and contraindications of different methods of treatment in patients with NGAIT, taking into account the parameters of severity of peroxide oxidation processes, the activity of apoptosis and functional capacity of the gland.

Keywords: nodular endemic goiter, autoimmune thyroiditis, apoptosis, cytokines, peroxidation, surgery volume.

\section{Abbreviations:}

NGAIT - nodular goiter with autoimmune thyroiditis; TG - thyroidgland; AOS - antioxidant systems; MA - malonic aldehyde; OMP - oxidative modification of proteins; $\mathrm{CP}$ - ceruloplasmin; GP - glutathione peroxidase; CT - catalase; TPOAB - thyroperoxidase antibodies, TGAB - thyroglobulin antibodies.

\section{INTRODUCTION}

There is an increasing scientific literaturedevoted to the study of apoptotic processes in nodular ter against the background of autoimmune thyroiditis $(\mathrm{AIT})^{1-8}$. However, data about markers involved in the regulation of apoptosis and proliferation in the thyroid gland tissues in patients withAIT appear to be rather disparate and sometimes contradictory, requiring systematization, so that their indices could be used to optimize the diagnosis and predict the course of nodular goiter with autoimmune thyroiditis ${ }^{9-15}$.

The mechanisms involved in the disturbances of regulation of the immune system in autoimmune du volume de la chirurgie chez les patients atteints de goitre nodulaire dans le contexte de la thyroïdite auto-immune, en tenant compte de l'activité des processus oxydants, auto-immuns et apoptotiques.

Materiel et methodes. Un total de 95 patients opérés d'un goitre endémique nodulaire sur le fond de thyroïdite auto-immune ont été examinés. Chez tous les patients avant et après la chirurgie on a évalué le statut des systèmes pro- et antioxydants, l'activité des cytokines pro-inflammatoires, la fonction hormonale de la glande thyroïde, le niveau d'anticorps anti-thyroperoxydase, les anticorps anti-thyroglobuline et les modifications structurelles de la glande thyroïde par ultrasons.

Résultats. L'analyse montre que chez les patients atteints de goitre nodulaire sur le fond de la thyroïdite auto-immune dans la période lointaine suivant un traitement chirurgical, il existe une augmentation significative de l'indice d'oxydation des peroxydes et une diminution de l'activité des systèmes de défense anti-oxydants contre la suppression des processus apoptotiques et l'activation des cytokines pro-inflammatoires. Ces processus entraînent des défaillances fonctionnelles, une hyperplasie et la progression des anomalies structurelles de la thyroïde, ce qui conduit finalement à la progression de l'incapacité fonctionnelle de la glande thyroïde et à l'issue du traitement à long terme inadéquate.

Conclusions. L'étude réalisée a permis de clarifier les indications et les contre-indications au choix des méthodes d'opération chez les patients atteints de goitre nodulaire endémique en combinaison avec de la thyroïdite auto-immune en tenant compte des paramètres des tests de sévérité des processus d'oxydation des peroxydes, de l'activité de l'apoptose et de la capacité fonctionnelle de la glande.

Mots-clés: goitre endémique nodulaire sur le fond de la thyroïdite auto-immune, apoptose, cytokines, oxydation au peroxyde, volume de la chirurgie.

pathology are of significant interest nowadays. The promising direction of this research is the study of apoptosis, which provides prompt removal of damaged and potentially dangerous cells in the body $y^{16-18}$. There is convincing evidence of the interrelationship between the disturbances in the regulation of apoptosis process and the development of autoimmune and other diseases, accompanied by a decrease in the effectiveness of immunological surveillance ${ }^{19-21}$. Some papers describe the mechanisms of inhibition and hyperactivation of immunity, which are associated with apoptosis modulation, including Fas-induced cell death ${ }^{22-26}$. CD95 antigen (also known as Fas or Apo-1) and Fas ligand play a key role in the apoptosis 
of immune system cells, both in the function of effector cytotoxic T-lymphocyte molecules and in the removal of activated lymphocytes by inhibiting immune response $\mathrm{e}^{22-26}$.

\section{The OBJECTIVE OF THE STUdY}

Identification of markers for predicting clinical course and choosing surgery volume in patients with nodular endemic goiter with autoimmune thyroiditis, taking into account the activity of oxidative, autoimmune and apoptotic processes.

\section{Materials AND Methods}

Surgical treatment was performed in 95 patients with unilateral nodular and multinodular goiter with autoimmune thyroiditis; unilateral goiter was diagnosed in $67(70.5 \%)$ of them and multi-nodular one in 28 (29.5\%) patients. The retrospective study was conducted between 2014-2017. The study has been approved by the ethics committee of the Chernivtsi Regional Hospital, Ukraine. The informed consent has been obtained from all the patients. The patients have been evaluated at 6 months and at 3 years after surgery. The postoperative check-up consisted in evaluation of the hormonal function of thyroid gland, the level of thyroperoxidase antibodies, thyroglobulin antibodies, and also thyroid ultrasonography.

The age of patients ranged from 18 to 45 years. The period of observation for patients in the remote postoperative period ranged from 6 months to 3 years. There were $11(11.5 \%)$ adolescent patients, $29(30.5 \%)$ patients aged between $18-30$ years, and $55(58 \%)$ patients aged between 31-45 years.

According to the results of the evaluation of the remote treatment outcomes (surgery and complex medicament treatment), the patients were divided into 2 subgroups. The $1^{\text {st }}$ subgroup involved 68 patients, with no progression of the disturbances of the thyroid gland functional state, according to the examination in the remote postoperative period; at ultrasound scan, these patients did not have a progression of structural changes, and the size of the remained thyroid lobe did not significantly differ from the preoperative one. The $2^{\text {nd }}$ subgroup consisted of 27 patients, in whom ultrasound scan revealed a deterioration of the structure, enlargement of the volume of the remained thyroid lobe, or the appearance of nodes on the background of progressive lymphoid infiltration of thyroid gland parenchyma. Thyroxine preparations were administered in individualized doses, as a replacement therapy, to maintain the TSH level within the reference values, from 0.4 to $4.0 \mathrm{mU} / \mathrm{mL}$.
The activity of peroxide oxidation and the state of antioxidant systems (AOS) was assessed, by determining the level of oxidative modification of proteins (OMP) in serum, and the activity of ceruloplasmin (CP). In erythrocytes, the content of malonic aldehyde (MA), the activity of glutathione peroxidase (GP) and catalase (CT) were estimated by conventional methods in patients of both subgroups, before surgery and during the remote postoperative period. In addition, the hormonal function of the thyroid gland, the level of thyroperoxidase antibodies (TPOAB), the level of thyroglobulin antibodies (TGAB) and structural changes in the gland (volume of the gland, nodular formation)by ultrasound scan were studied.

The content of lymphocytes bearing the apoptosis marker - the CD95+ receptor, the level of apoptosis in the population of peripheral annexin $\mathrm{V}+$ lymphocytes, the content of tumor necrosis factor- $\alpha$ (TNF- $\alpha$ ) in blood plasma, the concentration of interferon- $\gamma$ (IFN- $\gamma$ ) and interleukin-1 $\beta$ (IL-1 $\beta)$ were studied. These indices were studied using the standard diagnostic kits, according to the technology recommended by the manufacturer.

In order to determine the norm indices and to conduct a comparative assessment, the same indices were studied in 25 apparently healthy women, aged 21-42 years (control group).

All patients were administered 300 units of $\alpha$-lipoic acid intravenously, the day before surgery and daily after it for 10 days, then tablet forms were prescribed at a dose of 300 units per day for three months, with a repetition of tablets at a dose of 300 units per day for a month, every six months. This is a medication with a targeted antioxidant effect ${ }^{27-29}$.

The treatment was extended by Lymphomyosot injections $1.1 \mathrm{~mL}$ intramuscularly,during five days, followed by five more injections every four days. After that, the medication was administered at a dose of 10-15 drops sublingually, three times a day $(30 \mathrm{~mL}$ per course). Repeated use of Lymphomyosot was undertaken every three months - five injections every four days, with continuation of sublingual application by the same scheme for 1 month. This medicine, according to scientific sources, improves the processes of intercellular space drainage, lymphatic drainage and microcirculation, normalizes the immunological defense of the organism and restores the activity of the immune-endocrine system of the body $y^{27-29}$.

\section{Results AND Discussion}

The general condition of patients was assessed as satisfactory before the treatment. The conducted analysis of the laboratory findings results showed that in patients of both subgroups before treatment, 
Table 1. Indices of oxidative state in the blood of patients with NGAIT before surgery and during the remote postoperative period.

\begin{tabular}{|c|c|c|c|c|c|}
\hline \multirow[b]{2}{*}{ Index } & \multirow[b]{2}{*}{$\begin{array}{l}\text { Donors } \\
(n=25)\end{array}$} & \multicolumn{2}{|c|}{ Before surgery } & \multicolumn{2}{|c|}{ During the remote postoperative period } \\
\hline & & $\begin{array}{c}\text { Subgroup } 1 \\
(n=68)\end{array}$ & $\begin{array}{c}\text { Subgroup } 2 \\
(n=27)\end{array}$ & $\begin{array}{c}\text { Subgroup } 1 \\
(n=68)\end{array}$ & $\begin{array}{c}\text { Subgroup } 2 \\
(n=27)\end{array}$ \\
\hline $\begin{array}{c}\text { MA, } \\
\mu \mathrm{mol} / \mathrm{L} \text { of } \\
\text { erythrocy-tes }\end{array}$ & $\begin{array}{c}8.17 \pm \\
1.21\end{array}$ & $\begin{array}{c}13.27 \pm 1.46 \\
p<0.05\end{array}$ & $\begin{array}{c}14.23 \pm 1.17 \\
p<0.05\end{array}$ & $9.46 \pm 1.12$ & $\begin{array}{c}13.82 \pm 1.23 \\
p<0.05 \\
p_{1}<0.05\end{array}$ \\
\hline $\begin{array}{l}\text { OMP,of optical } \\
\text { density/g of } \\
\text { protein }\end{array}$ & $\begin{array}{c}39.61 \pm \\
1.23\end{array}$ & $\begin{array}{c}56.63 \pm 1.77 \\
p<0.05\end{array}$ & $\begin{array}{c}55.93 \pm 1.63 \\
p<0.05\end{array}$ & $42.97 \pm 1.72$ & $\begin{array}{c}54.62 \pm 1.92 \\
p<0.05 \\
p_{1}<0.05\end{array}$ \\
\hline
\end{tabular}

Note. $\mathrm{p}$ - level of statistical difference compared with similar parameters in healthy donors; $\mathrm{p}_{1}$ - level of statistical difference between the groups before starting the observation and 3 years after the treatment.

Table 2. Indices of antioxidant blood protection in patients with NGAIT before surgery and during the remote postoperative period

\begin{tabular}{|c|c|c|c|c|c|}
\hline \multirow[b]{2}{*}{ Index } & \multirow{2}{*}{$\begin{array}{l}\text { Donors } \\
(n=25)\end{array}$} & \multicolumn{2}{|c|}{ Before surgery } & \multicolumn{2}{|c|}{ During the remote postoperative period } \\
\hline & & $\begin{array}{c}\text { Subgroup } 1 \\
(n=68)\end{array}$ & $\begin{array}{c}\text { Subgroup } 2 \\
(n=27)\end{array}$ & $\begin{array}{c}\text { Subgroup } 1 \\
(n=68)\end{array}$ & $\begin{array}{c}\text { Subgroup } 2 \\
(n=27)\end{array}$ \\
\hline $\begin{array}{c}\mathrm{CT} \\
\mu \mathrm{mol} / \mathrm{min} \times \mathrm{g} \mathrm{Hb}\end{array}$ & $\begin{array}{c}168.73 \\
\pm 5.40\end{array}$ & $\begin{array}{c}148.27 \pm 5.07 \\
p<0.05\end{array}$ & $\begin{array}{c}138.51 \pm 4.69 \\
p<0.05\end{array}$ & $163.41 \pm 5.72$ & $\begin{array}{c}141.96 \pm 5.43 \\
p<0.05 \\
p_{1}<0.05\end{array}$ \\
\hline $\mathrm{GP}, \mu \mathrm{mol} / \mathrm{min} \times \mathrm{g} \mathrm{Hb}$ & $\begin{array}{l}205.0 \pm \\
7.22\end{array}$ & $\begin{array}{c}167.81 \pm 6.73 \\
p<0.05\end{array}$ & $\begin{array}{c}161.32 \pm 7.68 \\
p<0.05\end{array}$ & $198.82 \pm 7.72$ & $\begin{array}{c}162.13 \pm 7.34 \\
p<0.05 \\
p_{1}<0.05\end{array}$ \\
\hline $\begin{array}{l}\text { CP,UN of optical } \\
\text { dens/g of protein }\end{array}$ & $\begin{array}{c}77.20 \pm \\
3.61\end{array}$ & $\begin{array}{c}58.64 \pm 4.16 \\
p<0.05\end{array}$ & $\begin{array}{c}56.12 \pm 3.87 \\
p<0.05\end{array}$ & $75.39 \pm 4.07$ & $\begin{array}{c}58.16 \pm 3.78 \\
p<0.05 \\
p_{1}<0.05\end{array}$ \\
\hline
\end{tabular}

Note. $\mathrm{p}$ - level of statistical difference compared with similar parameters in healthy donors; $\mathrm{p}_{1}$ - level of statistical difference between the groups before starting the observation and 3 years after the treatment.

the activation of the peroxidation processes occurred (Table 1). This was manifested by the increase in MA and OMP rates compared to control $(\mathrm{p}<0.05)$.

A reliable decrease in the activity of peroxide oxidation processes was determined in patients of the $1^{\text {st }}$ subgroup during the remote postoperative period. However, in patients of the $2^{\text {nd }}$ subgroup, these indices practically did not differ from those before surgery (Table 1).

It was found that the activity of enzymes of antioxidant protection in patients from both subgroups was lower than in donors. During the remote postoperative period, the indices of AOS significantly increased in patients from the $1^{\text {st }}$ group, and in patients from the $2^{\text {nd }}$ subgroup, they practically did not differ from those of donors and before the beginning of observation (Table 2).

In patients from the $1^{\text {st }}$ subgroup, there was a significant increase in the content of CD95+ lymphocytes in peripheral blood, compared to healthy donors (Table 3).

The apoptotic activity of the lymphocytes (the number of annexin V-presenting cells) in patients with NGAIT, on the contrary, was significantly lower than normal. In addition, an increase in TNF- $\alpha$, INF- $\gamma$ and IL-1 $\beta$ rates was detected in the serum ofpatients with NGAIT,compared with the control group.

In the remote postoperative period, in patients from the $2^{\text {nd }}$ subgroup there was a reliable decrease in the level of cytokines - the concentration of TNF- $\alpha$, INF- $\gamma$ and IL-1 $\beta$ in serum decreased by more than twice. In addition, the number of annexin V-presenting cells of lymphocytes and the average content of CD95 + lymphocytes were close to the control values.

A retrospective comparison of ultrasound data, hormonal activity of the thyroid gland, TPOAB titer and $T G A B$ revealed that, prior to surgery, the volume of the gland lobe without nodes did not differ significantly in patients from the $1^{\text {st }}$ and $2^{\text {nd }}$ subgroups; the level of antibodies to TPOAB reliably differed, their indices were higher in the $2^{\text {nd }}$ subgroup than in the $1^{\text {st }}$ subgroup.

According to the ultrasound scan, the remained thyroid tissue was characterized by even echostructure in all parts of the thyroid gland lobe, a diffuse uniform decrease of the parenchymal echogenicity in $47(69 \%)$ patients from the $1^{\text {st }}$ subgroup during the remote postoperative period, against the background 
Table 3. Indices of apoptosis of peripheral blood lymphocytes and cytokine concentration in blood serum in patients with NGAIT before surgery and during the remote postoperative period.

\begin{tabular}{|c|c|c|c|c|c|}
\hline \multirow[b]{2}{*}{ Index } & \multirow[b]{2}{*}{ Donors $(n=25)$} & \multicolumn{2}{|c|}{ Before surgery } & \multicolumn{2}{|c|}{ During the remote postoperative period } \\
\hline & & $\begin{array}{c}\text { Subgroup I } \\
(n=68)\end{array}$ & $\begin{array}{c}\text { Subgroup II } \\
(n=27)\end{array}$ & $\begin{array}{c}\text { Subgroup I } \\
(n=68)\end{array}$ & $\begin{array}{c}\text { Subgroup II( } \\
n=27)\end{array}$ \\
\hline $\begin{array}{c}\text { CD95+ } \\
\text { lymphocytes, \% }\end{array}$ & $11.61 \pm 0.58$ & $\begin{array}{c}17.64 \pm \\
0.67 \\
p<0.05\end{array}$ & $\begin{array}{c}17.79 \\
\pm 0.62 \\
p<0.05\end{array}$ & $\begin{array}{c}12.04 \pm \\
0.58\end{array}$ & $\begin{array}{c}16.07 \\
\pm 0.64 \\
p<0.01 \\
p_{1}<0.05\end{array}$ \\
\hline $\begin{array}{c}\text { Number of } \\
\text { annexin } V^{+} \\
\text {lymphocytes, \% }\end{array}$ & $17.58 \pm 1.69$ & $\begin{array}{c}9.32 \pm \\
1.64 \\
p<0.05\end{array}$ & $\begin{aligned} & 10.12 \\
& \pm 1.37 \\
& p<0.001\end{aligned}$ & $\begin{array}{c}16.52 \pm \\
1.34\end{array}$ & $\begin{aligned} 10.58 \\
\pm 1.48 \\
\mathrm{p}<0.05 \\
\mathrm{p}_{1}<0.001\end{aligned}$ \\
\hline $\begin{array}{l}\text { Concentration of } \\
\text { TNF- } \alpha, \\
\text { pg/ml }\end{array}$ & $1.69 \pm 0.27$ & $\begin{array}{c}8.11 \pm \\
0.61 \\
p<0.001\end{array}$ & $\begin{array}{c}8.24 \\
\pm 0.79 \\
p<0.05 \\
p_{1}<0.05\end{array}$ & $\begin{array}{c}2.31 \pm \\
0.57\end{array}$ & $\begin{array}{c}7.14 \\
\pm 0.69 \\
p<0.05 \\
p_{1}<0.05\end{array}$ \\
\hline $\begin{array}{l}\text { Concentration of } \\
\text { INF- } \gamma \\
\mathrm{pg} / \mathrm{mL}\end{array}$ & $1.32 \pm 0.11$ & $\begin{array}{c}8.44 \pm \\
0.69 \\
p<0.001\end{array}$ & $\begin{array}{c}9.11 \\
\pm 2.19 \\
p<0.05\end{array}$ & $\begin{array}{c}2.44 \pm \\
0.27\end{array}$ & $\begin{array}{c}7.49 \\
\pm 0.71 \\
p<0.05 \\
p_{1}<0.05\end{array}$ \\
\hline $\begin{array}{l}\text { Concentration of } \\
\text { IL-1 } 1 \beta, \mathrm{pg} / \mathrm{mL}\end{array}$ & $1.96 \pm 0.23$ & $\begin{aligned} & 7.82 \pm \\
& 0.61 \\
p & <0.001\end{aligned}$ & $\begin{array}{c}7.49 \\
\pm 0.62 \\
p<0.05\end{array}$ & $\begin{array}{l}3.15 \pm \\
0.39\end{array}$ & $\begin{array}{c}6.79 \\
\pm 0.64 \\
p<0.05 \\
p_{1}<0.05\end{array}$ \\
\hline
\end{tabular}

Note. $\mathrm{p}$ - level of statistical difference compared with similar parameters in healthy donors; $\mathrm{p}_{1}$ - level of statistical difference between the groups before starting the observation and 3 years after the treatment.

Table 4. Comparative estimation of the lobe volume and functional state of the thyroid gland in patients before surgery and during the remote postoperative period.

\begin{tabular}{|c|c|c|c|c|c|}
\hline \multirow[b]{2}{*}{ Index } & \multirow[b]{2}{*}{ Donors } & \multicolumn{2}{|c|}{ Before surgery } & \multicolumn{2}{|c|}{ During the remote postoperative period } \\
\hline & & $\begin{array}{c}\text { Subgroup } 1 \\
(n=68)\end{array}$ & $\begin{array}{c}\text { Subgroup } 2 \\
(n=27)\end{array}$ & $\begin{array}{c}\text { Subgroup } 1 \\
(n=68)\end{array}$ & $\begin{array}{c}\text { Subgroup } 2 \\
(n=27)\end{array}$ \\
\hline $\begin{array}{l}\text { Volume of the } \\
\text { thyroid gland lobe } \\
\text { without nodes }\left(\mathrm{cm}^{3}\right)\end{array}$ & $7.5 \pm 0.17$ & $\begin{array}{c}10.18 \pm 0.25 \\
p<0.05\end{array}$ & $\begin{array}{c}10.42 \pm 0.91 \\
\mathrm{p}<0.05\end{array}$ & $\begin{array}{c}9.27 \pm 0.23 \\
p<0.05\end{array}$ & $\begin{array}{c}20.86 \pm 1.17 \\
p<0.05 \\
p_{1}<0.05\end{array}$ \\
\hline Free $\mathrm{T}_{4}, \mathrm{pmol} / \mathrm{L}$ & $17.5 \pm 0.23$ & $\begin{array}{c}15.52 \pm 0.19 \\
p<0.05\end{array}$ & $\begin{array}{c}13.02 \pm 0.21 \\
p<0.05\end{array}$ & $\begin{array}{c}13.8 \pm 0.19 \\
p<0.05\end{array}$ & $\begin{array}{l}5.83 \pm 0.46 \\
p<0.05 \\
p_{1}<0.05\end{array}$ \\
\hline TPOAB, $\mathrm{U} / \mathrm{mL}$ & $15.25 \pm 1.17$ & $\begin{array}{c}73.21 \pm 0.19 \\
p<0.05\end{array}$ & $\begin{array}{c}82.44 \pm 1.15 \\
\mathrm{p}<0.05\end{array}$ & $\begin{array}{c}74.45 \pm 0.56 \\
p<0.05\end{array}$ & $\begin{array}{c}215.68 \pm 1.88 \\
p<0.05 \\
p_{1}<0.05\end{array}$ \\
\hline TGAB, U/mL & $12.75 \pm 0.67$ & $\begin{array}{c}73.15 \pm 0.49 \\
p<0.05\end{array}$ & $\begin{array}{c}93.23 \pm 1.23 \\
\mathrm{p}<0.05\end{array}$ & $\begin{array}{c}78.49 \pm 0.49 \\
p<0.05\end{array}$ & $\begin{array}{c}135.27 \pm 1.52 \\
\mathrm{p}<0.05 \\
\mathrm{p}_{1}<0.05\end{array}$ \\
\hline
\end{tabular}

Note. $\mathrm{p}$ - level of statistical difference compared with similar parameters in healthy donors; $\mathrm{p}_{1}$ - level of statistical difference between the groups before starting the observation and 3 years after the treatment.

of anti-oxidant and lymph drainage therapy. Even contours of the thyroid gland were visualized in 21 (31\%) patients from the $1^{\text {st }}$ subgroup, slightly unevenscalloped contours of the thyroid tissue were echographically detected. At the same time, the thyroid volume decreased from 10.18 to $9.27 \mathrm{~cm}^{3}$ (Table 4). The color Doppler examination revealed blood flow improvement throughout the thyroid gland.

In $16(59 \%)$ patients from the $2^{\text {nd }}$ subgroup, the ultrasound of the thyroid gland revealed a sharp increase in echogenicity, an increase in the heterogeneity of the echostructure, due to the foci of increased echogenicity in the form of linear sections of irregular shape and varying sizes. There was a pronounced lobularity of the gland, with uneven contour.

In 11 patients, monitored 3-years postoperatively, the ultrasound scan revealed pseudo-nodes and nodes in the remaining part of the gland; pseudo-nodes were detected in $5(18.5 \%)$ of them; in $4(14.8 \%)$ patients, 
Table 5. Structural and functional changes of thyroid remain in patients with NGAIT during the nearest and remote postoperative period.

\begin{tabular}{|c|c|c|c|c|}
\hline \multirow[b]{2}{*}{ Signs } & \multicolumn{2}{|c|}{2 months after surgery } & \multicolumn{2}{|c|}{ During the distant postoperative period } \\
\hline & $\begin{array}{c}\text { Subgroup } 1 \\
(n=68)\end{array}$ & $\begin{array}{c}\text { Subgroup } 2 \\
(n=27)\end{array}$ & $\begin{array}{c}\text { Subgroup } 1 \\
(n=68)\end{array}$ & $\begin{array}{c}\text { Subgroup } 2 \\
(n=27)\end{array}$ \\
\hline $\begin{array}{l}\text { Changes in the thyroid tissue } \\
\text { echogenicity }\end{array}$ & ++ & ++ & + & $+++\mathrm{N}=27$ \\
\hline $\begin{array}{l}\text { Lobularity of the gland with } \\
\text { the tuberous, uneven contour }\end{array}$ & + & ++ & - & $+++\mathrm{N}=27$ \\
\hline \multirow{2}{*}{$\begin{array}{l}\text { Formation of pseudo-nodes } \\
\text { Formation of nodes }\end{array}$} & - & $N=3$ & - & $N=5$ \\
\hline & - & $\mathrm{N}=4$ & - & $N=6$ \\
\hline $\begin{array}{c}\text { L-thyroxine dose } \\
(\mu \mathrm{g} / \text { day })\end{array}$ & $25.5 \pm 0.19$ & $\begin{array}{c}37.5 \pm 2.25 \\
\mathrm{p}<0.05\end{array}$ & $\begin{array}{c}20.5 \pm 0.14 \\
\mathrm{p}_{1}<0.05\end{array}$ & $\begin{array}{c}88.8 \pm 3.29 \\
\mathrm{p}_{1}<0.05\end{array}$ \\
\hline
\end{tabular}

Note 1: studied ultrasound signs: +++ - pronounced; ++ - slightly pronounced; + - not pronounced; Note 2: $\mathrm{p}$ - compared with the indices after 2 months of treatment, $\mathrm{p}_{1}$ - compared with the distant treatment terms, $\mathrm{p}<0.05$.

there were rare nodes sized from 1.5 to $3.1 \mathrm{~cm}^{3}$, and in $2(7.7 \%)$ patients, 2 nodes of different echogenicity and echostructure, with a total volume of 17.3 and 18.5 $\mathrm{cm}^{3}$, were diagnosed. In this case, the volume of the thyroid remained increased, from 10.42 to $20.86 \mathrm{~cm}^{3}$. Blood flow disturbances throughout the thyroid gland were revealed by Doppler color mapping (Table 5).

In patients from the $1^{\text {st }}$ subgroup, the dose of replacement therapy with L-thyroxine, for the 2-month postoperatively, in 37 cases was not changed, in 23 patients there was the need to increase it by $12.5 \mu \mathrm{g}$ and in 8 cases the dose was increased on average by $37.5 \mu \mathrm{g}$ per day. During the postoperative period of observation, 23 patients received the same dose of replacement therapy as the initial one, in 38 patients it was on average increased by $12.5 \mu \mathrm{g}$ per day, and in 7 patients replacement therapy was not expedient (Table 5).

The dose of thyroxine replacement therapy, during 2 months of postoperative observation,remained the same in 3 patients of the second subgroup, in 14 patients increased by an average of $37.5 \mu \mathrm{g}$ and in 10 patients increased by an average of $54.5 \mu \mathrm{g}$ per day. During the remote postoperative period, the dose of replacement therapy in all patients increased by an average of $50.7 \mu \mathrm{g}$ per day (Table 5).

Antioxidant and lymph drainage therapy during the remote postoperative period led to a decrease in TPOAB and TGAB in patients of the first subgroup. Progression of AIT was detected in patients of the $2^{\text {nd }}$ subgroup, against the background of complex treatment; it was manifested by a reliable increase in the level of TGAB.

Our study has found that the significant increase of peroxide oxidation indices and decrease in the activity of antioxidant defense systems, against the background of apoptotic processes inhibition and pro-inflammatory cytokines activation, revealed in the remote period after surgical treatment of NGAIT in patients of the second subgroup, led to functional failure, hyperplasia and structural thyroid impairments progression, which ultimately result in the progression of functional failure of the thyroid gland and poor remote treatment outcomes.

Thus, the remote results of NGAIT treatment were considered satisfactory in patients of the first subgroup, and unsatisfactory - in patients of the second subgroup. The results were considered satisfactory due to the fact that positive dynamics in the structure of thyroid parenchyma was noted in the $1^{\text {st. }}$ subgroup, namely, according to the ultrasound scan, the remaining thyroid tissue was characterized by even echostructure in all parts of the thyroid gland lobe, and diffuse uniform decrease in the parenchymal echogenicity. At the same time, at ultrasonography, clear, even contours of the thyroid gland were visualized, and slightly uneven scalloped contours of the thyroid tissue. Doppler color mapping revealed blood flow improvement throughout the thyroid gland. This led to the stabilization of the thyroid gland functional capacity and to the decrease in the replacement therapy dose in some patients during the postoperative period. Hemithyroidectomy is expedient in such patients.

The reason for the unsatisfactory results of the treatment (surgery and medical treatment) is the progression of structural defects in the thyroid. In patients of the $2^{\text {nd }}$ subgroup, the ultrasound examination showed a pronounced increase in the echogenicity of the thyroid gland, an increase in the heterogeneity of echostructure, due to increased echogenicity of the thyroid tissue in the form of linear sections of irregular shape and varying sizes, a pronounced lobularity of the gland with tuberous, uneven contour. 
Table 6. Discriminant Function Analysis Summary Wilks' Lambda: 0.03051 approx. $F(18.72)=18.902 p<0.0000$

\begin{tabular}{|c|c|c|c|c|}
\hline \multirow{2}{*}{ Findings } & \multicolumn{4}{|c|}{ Statistical data } \\
\hline & Wilks' Lambda & Partial Lambda & F-remove - (2.36) & p-value \\
\hline 1 & 2 & 3 & 4 & 5 \\
\hline Thyroid gland volume, $\mathrm{cm}^{3}$ & 0.074579 & 0.877086 & 16.1160 & 0.000107 \\
\hline Free $\mathrm{T}_{4} \mathrm{pmol} / \mathrm{L}$ & 0.065439 & 0.999591 & 0.0470 & 0.828762 \\
\hline $\mathrm{TPOAB}, \mathrm{U} / \mathrm{mL}$ & 0.070339 & 0.929952 & 8.6623 & 0.003931 \\
\hline TGAB, U/mL & 0.083251 & 0.832651 & 8.1943 & 0.004122 \\
\hline MA, $\mu \mathrm{mol} / \mathrm{L}$ of erythrocytes & 0.246370 & 0.995802 & 7.4848 & 0.003133 \\
\hline OMP, UN of optical density/g of protein & 0.245342 & 0.999973 & 7.0030 & 0.003985 \\
\hline $\mathrm{CT}, \mu \mathrm{mol} / \mathrm{min} \times \mathrm{g} \mathrm{Hb}$ & 0.235129 & 0.989231 & 1.61291 & 0.207120 \\
\hline $\mathrm{GP} \mu \mathrm{mol} / \mathrm{min} \times \mathrm{g} \mathrm{Hb}$ & 0.283609 & 0.865048 & 17.9405 & 0.000046 \\
\hline TNF- $\alpha, \mathrm{pg} / \mathrm{mL}$ & 0.245883 & 0.997774 & 17.2565 & 0.000097 \\
\hline $\mathrm{INF}-\gamma, \mathrm{pg} / \mathrm{mL}$ & 0.247646 & 0.990670 & 17.0831 & 0.000085 \\
\hline $\mathrm{IL}-1 \beta, \mathrm{pg} / \mathrm{mL}$ & 0.250432 & 0.979651 & 8.3887 & 0.002973 \\
\hline CP, UN of optical density/g of protein & 0.248740 & 0.986313 & 1.5958 & 0.209050 \\
\hline CD95+lymphocytes, \% & 0.341544 & 0.718314 & 45.0970 & 0.00000 \\
\hline annexin $\mathrm{V}+$ lymphocytes, $\%$ & 0.253336 & 0.968422 & 28.7498 & 0.00000 \\
\hline
\end{tabular}

In this case, the formation of pseudo-nodes and nodes of different echogenicity and echostructure was detected. Doppler color mapping revealed blood flow slowing throughout the thyroid gland, which led to the inhibition of the thyroid gland functional capacity, clinical hypothyroidism development and to the increase in the replacement therapy dose. It is obvious that thyroidectomy was recommended for these patients.

The discriminant and correlation analysis of the studied indices (Figure 1, Table 6) was conducted, to study the diagnostic and prognostic value of the results for predicting the remote therapeutic results in patients with NGAIT.

The analysis revealed a high diagnostic value of the volume of the thyroid gland lobe without nodes (direct dependence, $\mathrm{p}<0.000107$ ), TSH level (direct dependence, $\mathrm{p}<0.000109$ ), the level of antibodies to TPO (direct dependence, $\mathrm{p}<0.003931$ ), the level of antibodies to TG (direct dependence, $\mathrm{p}<0.004122$ ), lower MA level (direct dependence, $\mathrm{p}<0.003133$ ); OMP activity (direct dependence, $\mathrm{p}<0.003985$ ); GP level (direct dependence, $\mathrm{p}<0.000046$ ); TNF- $\alpha$ concentration (direct dependence, $\mathrm{p}<0.000097$ ); INF- $\gamma$ (direct dependence, $\mathrm{p}<0.000085$ ); IL-1 $\beta$ (direct dependence, $\mathrm{p}<0.002973$ ); apoptosis indices - CD95+ lymphocytes (direct dependence, $\mathrm{p}<0.0000$ ); the number of annexin $\mathrm{V}+$ lymphocytes (direct dependence, $\mathrm{p}<0.00000$ ). The diagnostic value of CT level (direct dependence, $\mathrm{p}<0.207120$ ) and CP level (direct dependence, $\mathrm{p}<0.209050$ ) was low and unreliable.
Due to this fact, there is a need to clarify the indications and contraindications to organ-saving operations (hemithyroidectomy) in patients with NGAIT, taking into account the indices of the severity of peroxide oxidation processes, the apoptosis activity and the thyroid gland functional capacity.

\section{Conclusions}

The risk of development of functional failure and hyperplasia of the contralateral lobe of the thyroid gland after hemithyroidectomy, in patients with nodular goiter and autoimmune thyroiditis, can be the volume of the thyroid lobe without nodes larger than $10 \mathrm{~cm}^{3}$, the level of free $T_{4}$ lower than $12.91 \mathrm{pmol} / \mathrm{L}$, the TPOAB level higher than $80.25 \mathrm{U} / \mathrm{mL}$, and the level of TGAB higher than $89.34 \mathrm{U} / \mathrm{mL}$, with the indices of activity of peroxide oxidation and apoptosis processes, in particular with the indices of peroxidation activity processes - MA level higher than 9.5 $\mathrm{mol} / \mathrm{L}$ of erythrocytes; OMP activity higher than 42.97 UN of optical density/g of protein; AOP indices - CT level lower than $163.41 \mu \mathrm{mol} / \mathrm{min} \times \mathrm{g} \mathrm{Hb}$; GP lower than $198.82 \mu \mathrm{mol} / \mathrm{min} \times \mathrm{g} \mathrm{Hb}$; CP lower than 75.39 UN of optical density/g of protein; cytokine level - TNF- $\alpha$ concentration higher than $2.31 \mathrm{pg} / \mathrm{mL}$; INF- $\gamma$ higher than $2.44 \mathrm{pg} / \mathrm{mL}$; IL-1 $\beta$ higher than $3.15 \mathrm{pg} / \mathrm{mL}$; apoptosis indices - CD95+ lymphocytes higher than $12.04 \%$; annexin $\mathrm{V}+$ lymphocytes lower than $16.52 \%$ (Figure 1, Table 6). 


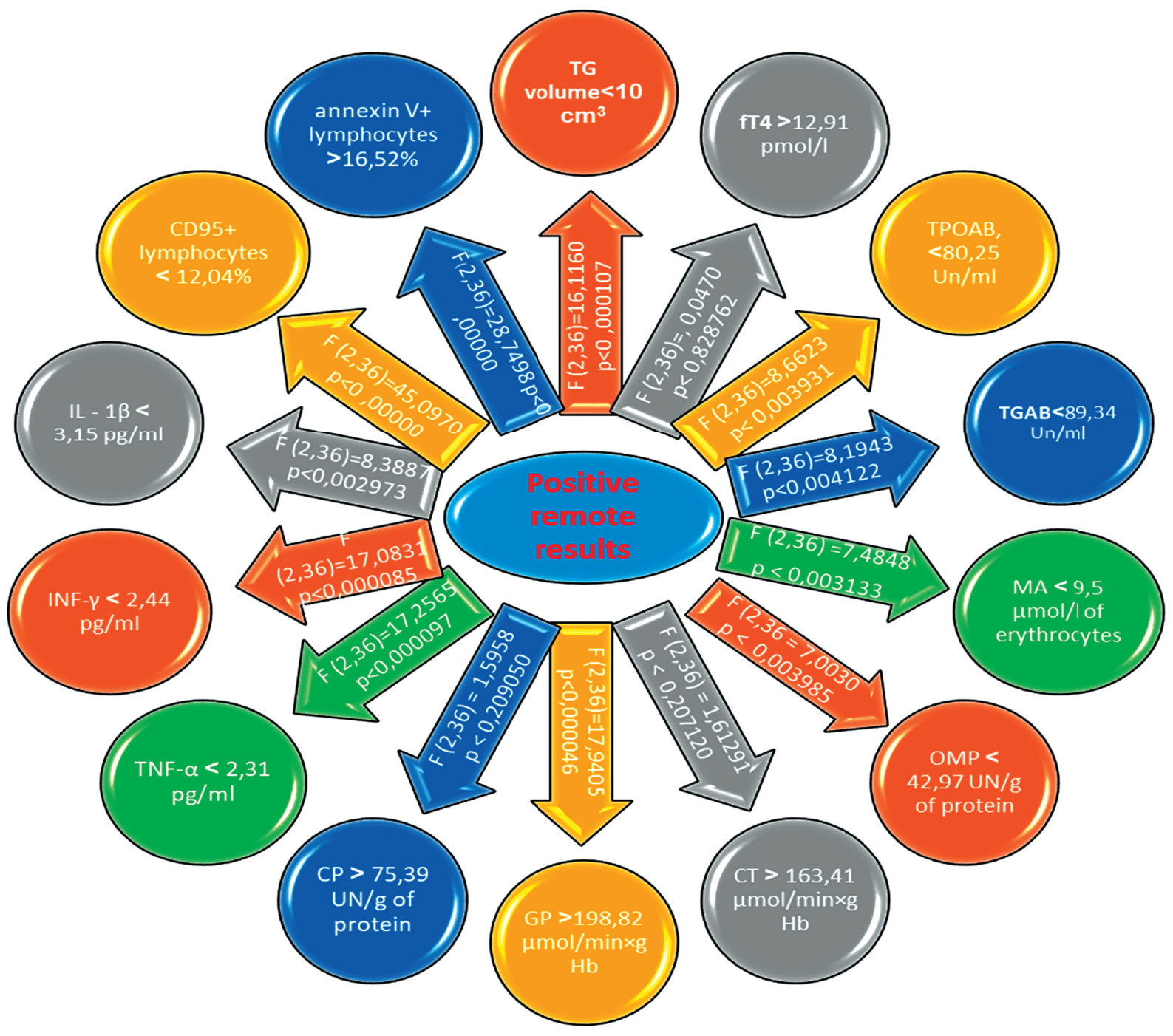

Figure 1. Results of the correlation analysis of tests aimed at predicting the remote outcomes of surgical treatment of nodular endemic goiter against the background of autoimmune thyroiditis (explanations are given in the text).

\section{Compliance with Ethics Requirements:}

„The authors declare no conflict of interest regarding this article"

"The authors declare that all the procedures and experiments of this study respect the ethical standards in the Helsinki Declaration of 1975, as revised in 2008(5), as well as the national law. Informed consent was obtained from all the patients included in the study"

"No funding for this study"

\section{References}

1. Shahrani AS, El-Metwally A, Al-Surimi K, et al. The epidemiology of thyroid diseases in the Arab world. Journal of Public Health and Epidemiology 2016;8(2):17-26.

2. Caturegli P, De Remigis A, Rose NR. Hashimoto's thyroiditis: clinical and diagnostic criteria. Autoimmun Rev 2014; 13:391-7.
3. Diana T, Krause J, Olivo PD, et al. Prevalence and clinical relevance of thyroid stimulating hormone receptor-blocking antibodies in autoimmune thyroid disease. Clin Exp Immunol 2017; 189:304.

4. Bai X, Sun J, Wang W, et al. Increased differentiation of Th22 cells in Hashimoto's thyroiditis. Endocr J 2014;61(12):1181-90.

5. Mikos H, Mikos M, Obara-Moszynska M, Niedziela M. The role of the immune system and cytokines involved in the pathogenesis of autoimmune thyroid disease (AITD). Endokrynol Pol 2014;65(2):150-5.

6. Ai J, Leonhardt JM, Heymann WR. Autoimmune thyroiddiseases: etiology, pathogenesis, and dermatologic manifestations. J Am Acad Dermatol 2003; 48: 641-659.

7. Cooper DS, Biondi B. Subclinical thyroid disease. Lancet 2012;379:1142-54.

8. Carrasco Llatas M, Seijas Rosales T, López Mollá C, Tamarit Conejeros JM, Fernández Martínez S, Dalmau Galofre J. Hemithyroidectomy: when it is necessary an intraoperative frozen-section biopsy? Acta Otorrinolaringol Esp 2008; 59(4):159-62. 
9. Diaconescu MR, Glod M, Costea I, Grigorovici M, Diaconescu S. Indications for surgery in thyroiditis. Chirurgia (Bucur) 2012; 107(3):337-42.

10. Erdal M, Sahin M, Hasimi A, Uckaya G, Kutlu M, Saglam K. Trace element level-s in Hashimoto's thyroiditis patients with subclinical hypothyroidism. Biol Trace Elem Res 2008;123(1-3):1-7

11. Nakahara M, Nagayama Y, Saitoh O, et al. Expression of immunoregulatory molecules by thyrocytes protects nonobesediabetic-H2h4 mice from developing autoimmune thyroiditis. Endocrinol 2009; 150:1545-1551.

12. Ganesh BB, Bhattacharya P, Gopisetty A, Prabhakar BS. Role of cytokines in the pathogenesis and suppression of thyroid autoimmunity. Journal of Interferon $\mathcal{E}$ Cytokine Research 2011;31(10):721-31.

13. Guan LJ, Wang X, Meng S, et al. Increased IL-21/IL-21R expression and its proinflammatory effects in autoimmune thyroid disease. Cytokine 2015;72(2):160-5.

14. Sheremet MI, Shidlovskyi VO, Sydorchuk LP. Assessmentof proliferation and apoptosis markers in patients with autoimmune thyroiditis. Journal of Education, Health and Sport 2016;6(1):179-188.

15. Rautureau GJ, Day CL, Hinds MG. Intrinsically disorderedproteins in bcl-2 regulated apoptosis. Int J Mol Sci 2010; 11(4):1808-1824.

16. Kinnally KW, Antonsson B. A tale of two mitochondrialchannels, MAC and PTP, in apoptosis. Apoptosis 2007; 12:857-868

17. Sheremet MI, Shidlovskyi VO, Sydorchuk LP. Analysis of aprocess of peroxidation, caspase- 3 and caspase- 8 in patientswith autoimmune thyroiditis. Journal of Education, Health and Sport 2015;5(11):117-125.

18. Erdamar H, Demirci H, Yaman H, et al. The effect of hypothyroidism, hyperthyroidism, and their treatment on parameters of oxidative stress and antioxidant status. Clin Chem Lab Med 2008;46 (7):1004-1010.

19. Bretz JD, Baker JR. Apoptosis and autoimmune thyroiddisease: following a TRAIL to thyroid destruction? Clin Endocrinol 2001; 55 (1): 1-11.
20. Seifman MA, Grodski SF, Bailey M, Yeung MJ, Serpell JW. Surgery in the setting of Hashimoto's thyroiditis. ANZ J Surg 2011;81(7-8):519-23.

21. Costanzo M, Caruso LA, Testa R, Marziani A, Cannizzaro MA. Hashimoto's thyroiditis. Possible cause or consequence of a malignant thyroid tumor. Ann Ital Chir 2006; 77(6):469_ 71.

22. Havasi A, Li Z, Wang Z, et al. Hsp27 inhibitsbax activation and apoptosis via a phosphatidylinositol3-kinase-dependent mechanism. J Biol Chem 2008; 283:12305-12313.

23. Sheremet MI, Sydorchuk LP, Shidlovskyi VO, Bedenyuk AD.Research of prognostic markers of proliferation and apoptosis in patients with nodular goiters combined with autoimmune thyroiditis. Arch Balk Med Union 2016; 51 (4): 488-491.

24. Dai R, Ahmed SA. MicroRNA, a new paradigm for understanding immunoregulation, inflammation, and autoimmune diseases. Transl Res 2011; 157:163-79.

25. Garber JR, Cobin RH, Gharib H, et al. Clinical practice guidelines for hypothyroidism in adults: cosponsored by the American Association of Clinical Endocrinologists and the American Thyroid Association. Endocr Pract 2012;18(6):988-1028.

26. Ramos-Levi AM, Marazuela M. Pathogenesis of thyroid autoimmune disease: the role of cellular mechanisms. Endocrinol Nutr 2016;63(8):421-9.

27. Sheremet MI, Sydorchuk LP, Shidlovskyi VO, et al. Remote results of hemithyroidectomy and their prognostication in patient with unilateral nodular goiter combined with autoimmune thyroiditis. Arch Balk Med Union 2018;53(1):41-46.

28. Sheremet MI. Optimization of complex treatment of patients with nodal forms of goiter on the background of auto-immune thyroiditis and prophylaxis of postoperative complications. Medical Forum 2017;12 (12): 125-129. [in Ukrainian])

29. Sheremet MI, Shidlovskyi VO, Shidlovskyi OV, et al. Drug therapy in autoimmune thyroiditis. Arch Balk Med Union 2018;53(3):373-80 